\title{
Metatinib Tromethamine
}

National Cancer Institute

\section{Source}

National Cancer Institute. Metatinib Tromethamine. NCI Thesaurus. Code C113294.

An orally bioavailable tyrosine kinase inhibitor of the BCR-ABL fusion oncoprotein, with potential antineoplastic activity. Upon oral administration, BCR-ABL tyrosine kinase inhibitor BL001 may inhibit the BCL-ABL protein, which may lead to decreased proliferation and enhanced apoptosis in tumor cells. BCR-ABL oncoprotein is generated by a reciprocal translocation between chromosome 9 and 22 specifically $t(9 ; 22)$ (q34;q11). The resulting fusion gene produces proteins with constitutively active tyrosine kinase activity, which stimulate both abnormal cell division and increased cellular proliferation. This fusion is associated with both chronic myeloid leukemia and acute lymphoblastic leukemia. 